\title{
How to select IgG subclasses in developing anti-tumor therapeutic antibodies
}

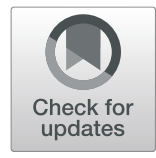

Jifeng $\mathrm{Yu}^{1,2^{*}}$, Yongping Song ${ }^{1 *}$ and Wenzhi Tian ${ }^{3^{*}}$

\begin{abstract}
The intact antibody of human immunoglobulin $(\mathrm{lgG})$ is composed of the fragment for antigen binding (Fab) and the crystallizable fragment $(F c)$ for binding of Fcy receptors. Among the four subclasses of human $\lg G(\lg G 1, \lg G 2, \lg G 3$, lgG4), which differ in their constant regions, particularly in their hinges and $\mathrm{CH} 2$ domains, lgG1 has the highest FcyRbinding affinity, followed by $\lg G 3, \lg G 2$, and $\lg G 4$. As a result, different subclasses have different effector functions such as antibody-dependent cell-mediated cytotoxicity (ADCC) and antibody-dependent cellular phagocytosis (ADCP). FCY receptors include six subtypes (FcyRI, FcyRIIA, FcyRIIB, FcyRIIC, FcyRIIIA, FcyRIIIB) which differ in cellular distribution, binding affinity to $\mathrm{Fc}$, and the resulting biological activity. Therefore, when developing anti-tumor therapeutic antibodies, including single-targeted antibodies, bi-specific antibodies (BsAbs), and antibody-drug conjugates (ADCs), many factors, such as target biology, cellular distribution of the targets, the environments of particular tumor types, as well as the proposed mechanism of action (MOA), must be taken into consideration. This review outlines fundamental strategies that are required to select lgG subclasses in developing anti-tumor therapeutic antibodies.
\end{abstract}

Keywords: Therapeutic antibody, lgG subclass, Fcy receptor, ADCC, ADCP

\section{Background}

Due to its high specificity and superior pharmacokinetics, the antibody drug has attracted great attention across the pharmaceutical industry since the late 1990s, especially following the inaugural approval of rituximab, the first anti-tumor antibody drug, in 1997. Anti-tumor antibody drugs exert therapeutic efficacy by several different, but not mutually exclusive, mechanisms [1], including (1) Fcmediated effector functions (ADCC, ADCP, CDC); (2) blocking tumor growth signals; (3) inhibiting angiogenesis; (4) triggering apoptotic pathways in tumor cells; (5) activating immune cells. Among the FDA-approved 22 antitumor antibodies (Table 1) [2-24], almost half (10) of

\footnotetext{
*Correspondence: yujifengzzu@163.com; songyongping001@126.com; wenzhi.tian@immuneonco.com

'Department of Hematology, The First Affiliated Hospital of Zhengzhou University, Zhengzhou 450052, China

${ }^{2}$ Academy of Medical and Pharmaceutical Sciences of Zhengzhou University, Zhengzhou 450052, China

3 ImmuneOnco Biopharmaceuticals (Shanghai) Co., Ltd., Shanghai 201203, China
}

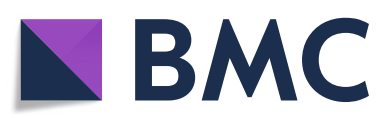

() The Author(s). 2020 Open Access This article is licensed under a Creative Commons Attribution 4.0 International License, which permits use, sharing, adaptation, distribution and reproduction in any medium or format, as long as you give appropriate credit to the original author(s) and the source, provide a link to the Creative Commons licence, and indicate if changes were made. The images or other third party material in this article are included in the article's Creative Commons licence, unless indicated otherwise in a credit line to the material. If material is not included in the article's Creative Commons licence and your intended use is not permitted by statutory regulation or exceeds the permitted use, you will need to obtain permission directly from the copyright holder. To view a copy of this licence, visit http://creativecommons.org/licenses/by/4.0/. The Creative Commons Public Domain Dedication waiver (http://creativecommons.org/publicdomain/zero/1.0/) applies to the data made available in this article, unless otherwise stated in a credit line to the data.

them engage in anti-tumor activity via Fc-mediated effector functions. The other half engaged via other mechanisms such as apoptosis induction or tumor growth signal blockage antibodies targeting immune checkpoints (such as PD-(L) 1 antibodies) usually act by neutralizing inhibitory signals [10], while CTLA-4 antibody ipilimumab activates immune function by depleting regulatory $\mathrm{T}$ cells (Tregs) from tumor microenvironment (TME) [11, 12].

IgG has four subclasses, named IgG1, IgG2, IgG3, and IgG4 [25]. Although all the subclasses have more than $90 \%$ identity on the amino acid level, each subclass however has a unique profile with respect to the length of hinge region, the number of inter-chain disulfide bonds, and Fc-effector functions. Differences in the profile of IgG subclasses are summarized in Table 2 [26]. Among the four IgG subclasses, IgG3 demonstrates the highest affinity binding to most Fc $\gamma$ Rs, but is not selected routinely as a therapeutic format due to its long hinge region and polymorphic nature, both of which increase the risk of stability and immunogenicity [28], thus IgG3 will 
Table 1 FDA approved tumor-therapeutic antibodies [2-24]

\begin{tabular}{|c|c|c|c|c|c|}
\hline Targeted drugs & IgG subclass & Target & Indications & Mechanism of action & Refs \\
\hline Rituximab (Rituxan) & $\lg G 1$ & CD20 & $\mathrm{NHL}$ & $\mathrm{ADCC} / \mathrm{CDC}$ & {$[2]$} \\
\hline Trastuzumab (Herceptin) & $\lg G 1$ & Her2 & Breast cancer & Growth signal blocking; ADCC & {$[3,4]$} \\
\hline Cetuximab (Erbitux) & $\lg G 1$ & EGFR & $\mathrm{mCRC}$ & Growth signal blocking; ADCC & {$[5]$} \\
\hline Bevacizumab & $\lg G 1$ & VEGF & Solid tumors & Angiogenesis inhibition & {$[6]$} \\
\hline Panitumumab (Vectibix) & $\lg G 2$ & EGFR & $\mathrm{mCRC}$ & Growth signal blocking & [7] \\
\hline Ofatumumab (Arzerra) & $\operatorname{lgG} 1$ & CD20 & CLL & $\mathrm{ADCC} / \mathrm{CDC}$ & [8] \\
\hline Alemtuzumab (Campath) & $\lg G 1$ & CD52 & $\mathrm{CLL}$ & $\mathrm{ADCC} / \mathrm{CDC}$ & [9] \\
\hline Denosumab (Xgeva) & $\lg G 1$ & RANKL & Bone tumor & Growth signal blocking & [10] \\
\hline Ipilimumab (Yervoy) & $\operatorname{lgG} 1$ & CTLA-4 & Solid tumors & Depleting Treg cells & {$[11,12]$} \\
\hline Pertuzumab (Perjeta) & $\lg G 1$ & Her2 & Breast cancer & Growth signal blocking & [13] \\
\hline Obinutuzumab (Gazyva) & $\operatorname{lgG} 1$ & CD20 & $\mathrm{CLL}$ & ADCC; apoptosis induction & [14] \\
\hline Ramucirumab (Cyramza) & $\lg G 1$ & VEGFR2 & Solid tumors & Angiogenesis inhibition & {$[15]$} \\
\hline Pembrolizumab (Keytruda) & $\lg G 4$ & PD-1 & Solid tumors & Neutralizing inhibitory signal in T cells & [16] \\
\hline Nivolumab (Opdivo) & $\lg G 4$ & PD-1 & Solid tumors & Neutralizing inhibitory signal in $T$ cells & {$[17]$} \\
\hline Dinutuximab (Unituxin) & $\operatorname{lgG} 1$ & GD2 & Neuroblastoma & $\mathrm{ADCC} / \mathrm{CDC}$ & {$[18]$} \\
\hline Daratumumab (Darzalex) & $\operatorname{lgG1}$ & CD38 & Multiple myeloma & ADCC/CDC; apoptosis induction & [19] \\
\hline Elotuzumab (Empliciti) & $\lg G 1$ & SLAMF7 & Multiple myeloma & $\begin{array}{l}\text { ADCC, direct activation } \\
\text { of NK cells }\end{array}$ & {$[20]$} \\
\hline Atezolizumab (Tecentriq) & $\lg G 1$ & PD-L1 & Solid tumors & Neutralizing inhibitory signal in T cells & {$[21]$} \\
\hline Avelumab (Bavencio) & $\operatorname{lgG1}$ & PD-L1 & Solid tumors & Neutralizing inhibitory signal in T cells; ADCC & {$[22]$} \\
\hline Durvalumab (Imfinzi) & $\operatorname{lgG1}$ & PD-L1 & Solid tumors & Neutralizing inhibitory signal in $T$ cells & [21] \\
\hline Mogamulizumab (Poteligeo) & $\lg G 1$ & CCR4 & $\mathrm{CTCL}$ & ADCC & [23] \\
\hline Cemiplimab (Libtayo) & $\lg G 4$ & PD-1 & Solid tumors & Neutralizing inhibitory signal in T cells & {$[24]$} \\
\hline
\end{tabular}

not be discussed further in this review. Of the remaining subclasses, IgG1 demonstrates the highest affinity for all FcyRs and is a potent activator of ADCC and ADCP. IgG4 only has high affinity for FcyRI but weak affinities for all other receptors, and is a poor inducer of Fcmediated effector functions. IgG2 has high affinity for

Table 2 Properties of human IgG subclasses and relative binding affinity with major FcyRs $[26,27]$

\begin{tabular}{lllll}
\hline & $\operatorname{lgG} 1$ & $\operatorname{lgG} 2$ & $\operatorname{lgG} 3$ & $\operatorname{lgG} 4$ \\
\hline Molecular mass (kD) & 146 & 146 & 170 & 146 \\
Amino acids in hinge region & 15 & 12 & 62 & 12 \\
Inter-heavy chain disulfide bonds & 2 & 4 & 11 & 2 \\
Complement activation (C1q binding) & ++ & + & +++ & - \\
FcyRl & 650 & - & 610 & 340 \\
FcyRIla-H131 & 52 & 4.5 & 8.9 & 1.7 \\
FcyRIla-R131 & 35 & 1 & 9.1 & 2.1 \\
FcyRllb & 1.2 & 0.2 & 1.7 & 2 \\
FcyRIIIa-V158 & 20 & 0.7 & 98 & 2.5 \\
FcyRIIla-F158 & 11.7 & 0.3 & 77 & 2 \\
\hline
\end{tabular}

the H131 form of FcyRIIA, but no measurable or weak affinity for Fc $\gamma$ RI and all other Fc $\gamma$ Rs (Table 2).

Human Fcy receptor family includes six members

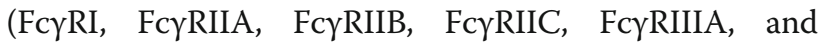
FcyRIIIB) which differ in cellular distribution, binding affinity to Fc, and the resulting biological activity. The

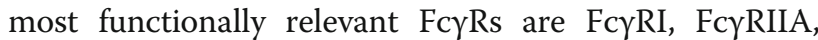

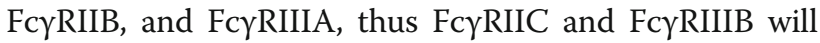
not be discussed in this review. Except for FcyRI, which is an activating receptor with high affinity for IgG and can be activated by monomeric IgG, all other Fc $\gamma$ Rs can only be functionally engaged by the Fc region of IgG when complexed with a specific antigen. FcyRIIB is the only inhibitory $F c \gamma R$ and is expressed on many immune cells including $\mathrm{B}$ cells, monocytes, macrophages, DCs, and mast cells (Table 3). When engaged with antigen-

Table 3 Cellular distribution of the major human FcyRs [29]

\begin{tabular}{ll}
\hline FcyR & Cellular distribution \\
\hline FcyRl & Monocytes, macrophages, activated neutrophils, DCs \\
FcyRIla & Monocytes, macrophages, neutrophils, DCs \\
FcyRllb & B cells, monocytes, macrophages, DCs, mast cells \\
FcyRIlla & NK cells, monocytes, macrophages \\
\hline
\end{tabular}


bound IgG, FcyRIIB transduces an inhibitory signal through the intracellular immunoreceptor tyrosinebased inhibitory motif (ITIM), resulting in inhibition of ADCC and ADCP [30]. The best characterized activating Fc $\gamma$ Rs are Fc $\gamma$ RIIA and Fc $\gamma$ RIIIA. Fc $\gamma$ RIIA is primarily expressed on monocytes and macrophages, while Fc $\gamma$ RIIIA is dominantly expressed on NK cells. Both the activating $\mathrm{Fc} \gamma \mathrm{Rs}$ have two allelic variants (Table 2), with FcyRIIA-H131 having an overall higher affinity for Fc than FcyRIIA-R131, and Fc $\gamma$ RIIIA-V158 having a higher affinity for Fc than FcyRIIIA-F158 [27, 29].

When developing cancer therapeutic antibodies, an appropriate subclass of human IgG must be selected to couple with the proposed MOAs. In this review, strategies for selection of IgG subclass based on the cellular distribution and biological natures of the targets in the development of single-targeted antibodies, bispecific antibodies (BsAbs), as well as ADC drugs will be discussed.

\section{Selection of IgG subclasses for single-targeted antibodies}

Antibodies against single targets for cancer therapy have been promising, especially for those with appropriately selected IgG subclass. Although there are not stringent criteria for the selection of IgG subclass for a singletargeted antibody, cellular distribution and the biological function of the targets should be considered when selecting the subclass.

\section{Selection of IgG subclasses for tumor cell targets}

Up to 12 targets expressed on tumor cells have been clinically validated (Table 1). Except for EGFR, for which both IgG1 and IgG2 were respectively selected for the formats of cetuximab and panitumumab, all other targets were paired with IgG1. Although Her2 and EGFR belong to the tyrosine kinase receptor family for which a targeted antibody may exert anti-tumor activity by blocking the growth signal, the ADCC and/or ADCP induced by the IgG1 antibodies (e.g., cetuximab and trastuzumab) against RTKs also play substantial therapeutic roles. Thus, when developing therapeutic antibodies against targets expressed on tumor cells, IgG1 should be primarily considered, for it has the best binding affinity for activating Fc $\gamma$ Rs and can elicit strong ADCC and/or ADCP activity against tumor cells. Additionally, when ADCP is activated, the effector cells (macrophages or dendritic cells) may present the processed tumor antigen to $\mathrm{T}$ cells, thus further eliciting a long-lasting tumorspecific adaptive immunity [31].

Some tumor cell targets are ligands for immune checkpoints (ICPs), such as PD-L1 and CD47, which are the interacting partner for PD-1 and SIRP $\alpha$, respectively. PD-1 and its ligand PD-L1 perform a vital role in tumor progression and survival by escaping tumor neutralizing immune surveillance. PDL-1 is expressed in tumor cells and antigen-presenting cells, and the engagement of PDL1 with PD-1 of T cell creates T cell dysfunction, exhaustion, neutralization, and interleukin-10 (IL-10) production in a tumor mass [32]. Therefore, blocking PD-1 or PD-L1 recognition process can block the inhibition signaling, consequently reactivate the effector $\mathrm{T}$ cells to kill tumor cells [33]. Although simply blocking PD-L1 could induce significant therapeutic efficacy, retention of the Fc-effector function in the IgG1 format would further improve the therapeutic efficacy. It was reported that Avelumab, an IgG1 anti-PD-L1 inhibitor, triggers NK cell-mediated cytotoxicity and cytokine production against triple-negative breast cancer cells [22].

Optimal induction of ADCC was dependent on the abundance of target expression on tumor cells, for which the minimal requirement per cell is $10^{5}-10^{6}$. Cells with target density less than $10^{5}$ are less likely to induce and thus will not be damaged by ADCC. Normal tissues usually express much lower level of the targets compared to tumor tissues [34].

\section{Selection of IgG subclasses for targets expressed in immune cells}

Selection of IgG subclasses for immune cell targets is more complicated because some targets act to regulate immune function by transducing inhibitory signals to $\mathrm{T}$ cells. These targets are immunoinhibitory receptors which are collectively referred to as immune checkpoints (ICP) (such as CTLA4, PD-1, TIM-3, LAG-3). Meanwhile, others are targets for activating immune cells (41BB, CD40, OX40, CD27, GITR, etc.), usually called immunostimulatory receptors. Among the best characterized immune checkpoints, PD-1, TIM-3, and LAG3 are mainly expressed in CD8 $\mathrm{T}$ lymphocytes, while CTLA-4 is primarily expressed in Treg cells in TME. As such, different strategies of IgG format should be carefully considered when developing therapeutic antibodies against different ICP. For example, IgG4 (but not IgG1) should be the primary antibody format for PD-1 antibody (all the currently approved PD-1 antibodies are in the IgG4 subclass format.) However, since IgG4 only has a high affinity to FcyRI but weak affinity to all other Fc $\gamma$ Rs and thus will not have a detectable Fc-mediated effector function meaning the CD8 $\mathrm{T}$ lymphocytes will not be eliminated accordingly, IgG1 should be selected for those ICPs mainly expressed in Tregs or other immunosuppressive cells, which can be depleted by the antibodies via the mechanism of ADCC/ADCP. Ipilimumab targeting CTLA-4 is such an antibody that exerts therapeutic efficacy mainly via ADCC/ADCP eliminating Tregs from TME $[11,12]$ so that more room can be made for effector $\mathrm{T}$ cells that can be activated by PD-1 
antibodies. There is one IgG2 antibody, tremelimumab, targeting CTLA-4 that has been under extensive clinical trials since 2006 [35]. Since IgG2 only has high affinity to FcyRIIa-H131 that is mainly expressed in macrophages that will not be fully activated in the absence of CD47-SIRP $\alpha$ blockers, tremelimumab would not be able to eliminate Tregs from TME, and thus would not be effective in cancer therapy. Point of fact, tremelimumab has unfortunately already failed six late-stage clinical trials thus far (Table 4) [36] https://www.pfizer.com/news/ press-release/press-release-detail/pfizer_announces_discontinuation_of_phase_iii_clinical_trial_for_patients with_advanced_melanoma., https://www.astrazeneca. $\mathrm{com} / \mathrm{media}-\mathrm{cen}$ tre/press-releases/2016/astrazeneca-reports-top-line-result-of-tremelimumab-monotherapytrial-in-mesothelioma-29022016.html\#!, https://www. astrazeneca.com/media-centre/press-releases/2018/astrazeneca-reports-results-from-the-arctic-trial-in-third-linenon-small-cell-lung-cancer-24042018.html, https://www. astrazeneca.com/media-centre/press-releases/2018/astrazeneca-provides-update-on-the-phase-iii-mystic-trial-ofimfinzi-and-tremelimumab-in-stage-iv-non-small-celllung-cancer16112018.html, http://www.pharmabiz.com/ NewsDetails.aspx?aid $=112740 \&$ sid $=2$, https: $/ / \mathrm{www}$. marketscreener.com/ASTRAZENECA-4000930/news/ AstraZeneca-Update-on-the-Phase-III-NEPTUNE-trial-2 9093768/. However, another study demonstrated that ipilimumab and tremelimumab increase the infiltration of intratumoral CD4+ and CD8+ cells without significantly changing or depleting FOXP3+ cells within the tumor microenvironment. It suggests that anti-CTLA-4 immunotherapy does not deplete FOXP3+ cells in human tumors, but their efficacy could be enhanced by modifying the Fc portions of the monoclonal antibodies to enhance Fc-mediated depletion of intratumoral regulatory $\mathrm{T}$ cells [37].

Most of the immunostimulatory receptors belong to the tumor necrosis factor receptor (TNFR) superfamily (such as 4-1BB, CD40, OX40, CD27, GITR), which upon engagement by agonistic antibodies, can stimulate immunity. In contrast to antibodies for immune checkpoint receptors (such as PD-1) for which pure target blocking can activate $\mathrm{T}$ cells, activation of a TNFR-superfamily member by antibody requires hyper cross-linking of the antibodies with FcyRs. For example, anti-CD40 mAb requires inhibitory FcyRIIB-mediated crosslinking for agonistic effect [38-40]. It has been documented that the anti-CD40 human IgG1 antibody produces potent antitumor activity in tumor models with the $\mathrm{mFc} \gamma \mathrm{R}$ $-/-h F C G R 2 B$ genotype, depleting (by N297A mutation) or increasing (by S267E mutation) the binding affinity to hFcyRIIB, respectively abrogating or enhancing antitumor activity [38]. This suggests FcyRIIB is absolutely required for antibodies targeting immunostimulatory receptors of TNFR superfamily members [41-44]. Additionally, the hinge region in the $\mathrm{CH} 1$ domain is also important and required for antibody agonistic function. The more rigid the hinges of a given IgG, the more stable the clustering of the immunostimulatory receptors on cell membranes and thus the greater the anti-tumor efficacy [45]. Replacement of the hinge region with that of IgG3 completely eliminated the anti-tumor activity of the anti-CD40 antibody, although both the CD40 and the $\mathrm{F} c \gamma \mathrm{R}$ binding affinity were retained. Even for the engineered IgG1-Fc with enhanced binding affinity to FcyRIIB [46], the original potent anti-tumor activity was completely lost. However, when combining the rigid hinge region with an engineered Fc domain stronger for FcyRIIB binding, anti-tumor activity significantly improved [45], indicating human $\mathrm{CH} 1$-hinge regions, selected for rigidity, and Fc domains engineered for Fc $\gamma$ RIIB engagement can synergize to enhance the immunostimulatory and anti-tumor activities of antibodies targeting TNFR superfamily members.

Safety is also a major concern for agonistic Abs since one antibody, urelumab, targeting $4-1 \mathrm{BB}$ has been

Table 4 Summary for failure of clinical trials for tremelimumab [36]

\begin{tabular}{|c|c|c|c|c|}
\hline Indications & Therapy & Stage & Code & Refs \\
\hline Advanced melanoma & Monotherapy & $\begin{array}{l}\text { Phase } \\
\text { llb }\end{array}$ & A3671009 & $\begin{array}{l}\text { https://www.astrazeneca.com/media-centre/press-releases/2018/astrazeneca- } \\
\text { reports-results-from-the-arctic-trial-in-third-line-non-small-cell-lung-cancer-24042 } \\
\text { 018.html }\end{array}$ \\
\hline Mesothelioma & Monotherapy & $\begin{array}{l}\text { Phase } \\
\text { llb }\end{array}$ & DETERMINE & $\begin{array}{l}\text { https://www.astrazeneca.com/media-centre/press-releases/2018/astrazeneca- } \\
\text { provides-update-on-the-phase-iii-mystic-trial-of-imfinzi-and-tremelimumab-in- } \\
\text { stage-iv-non-small-cell-lung-cancer16112018.html }\end{array}$ \\
\hline $\begin{array}{l}\text { Previously treated } \\
\text { NSCLC }\end{array}$ & $\begin{array}{l}\text { Durvalumab plus } \\
\text { tremelimumab }\end{array}$ & $\begin{array}{l}\text { Phase } \\
\text { III }\end{array}$ & ARCTIC & http://www.pharmabiz.com/NewsDetails.aspx?aid $=112740 \&$ sid $=2$ \\
\hline $\begin{array}{l}\text { Previously untreated } \\
\text { NSCLC }\end{array}$ & $\begin{array}{l}\text { Durvalumab plus } \\
\text { tremelimumab }\end{array}$ & $\begin{array}{l}\text { Phase } \\
\text { III }\end{array}$ & MYSTIC & $\begin{array}{l}\text { https://www.marketscreener.com/ASTRAZENECA-4000930/news/AstraZeneca- } \\
\text { Update-on-the-Phase-III-NEPTUNE-trial-29093768/ }\end{array}$ \\
\hline HNSCC & $\begin{array}{l}\text { Durvalumab plus } \\
\text { tremelimumab }\end{array}$ & $\begin{array}{l}\text { Phase } \\
\text { III }\end{array}$ & EAGLE & {$[37]$} \\
\hline $\begin{array}{l}\text { Previously untreated } \\
\text { NSCLC with high TMB }\end{array}$ & $\begin{array}{l}\text { Durvalumab plus } \\
\text { tremelimumab }\end{array}$ & $\begin{array}{l}\text { Phase } \\
\text { III }\end{array}$ & NEPTUNE & [38] \\
\hline
\end{tabular}


stopped for clinical trials following the occurrence of two hepatotoxicity-related deaths [47]. Another 4-1BB antibody, utomilumab [48], showed better safety profiles but is less potent relative to urelumab, with no encouraging efficacy data has been observed thus far as a monotherapy. Analysis on these two Abs indicated that urelumab is a fully human IgG4 with a hinge mutation (S228P) to improve stability $[49,50]$ and is a more potent agonist since it can co-stimulate $\mathrm{T}$ cells in the absence of $\mathrm{Fc} \gamma \mathrm{R}$ [51, 52], while utomilumab, a fully human IgG2 [48], requires FcyRIIB-expressing cells for its agonistic activity, and thus is a weak agonistic Ab. Accumulated clinical data was not promising for either antibody [53]. Efforts have been made to mitigate the liver toxicity and improve the efficacy of 4-1BB antibodies $[52,54]$ by engineering the Fc portion of the antibody to eliminate binding to the activating Fc $\gamma R s$, including Fc $\gamma R I, F c \gamma R I I A$, and Fc $\gamma R I I I A$, while retaining binding to the inhibitory Fc receptor FcyRIIB [52]. Alternatively, antibodies targeting different epitopes away from the ligand-binding sites may have better efficacy as well as safety profiles if they are IgG4, which have better binding affinity to FcyRIIB than IgG2, which only binds to FcyRIIA [54].

Collectively, the IgG1 subclass should be preferentially considered when developing antibody drugs targeting tumor antigens, especially when the Fc-mediated effector function is the main mode of action for tumor therapy. Selection of IgG subclass format for targets in immune cells should be done with careful consideration to the nature of the targets. If ICPs are expressed on effector immune cells, then IgG4 should be preferentially considered. If expressed on Tregs or other immunosuppressive cells such as M2 macrophages or myeloid-derived suppressive cells (MDSC), then IgG1 should be selected. For targets with immunostimulatory function, especially for those of the TNFR superfamily members, IgG should be engineered to have enhanced FcyRIIB engagement besides epitope screening.

\section{Selection of IgG subclass format in bispecific antibody development}

Due to the limitations of the treatment response as well as therapeutic efficacy for single target-specific antibodies in addressing cancer indications, bispecific antibody (BsAb) drug development has emerged as an attractive focus of biopharmaceutical companies globally. Although the concept of dual-targeted therapy is promising, translation of the concept into therapeutic products is challenging in several aspects: (1) CMC is complex due to mismatch of the heavy and light chains from respective monoclonal antibodies; (2) target pairing is scientifically challenging due to the general lack of detailed study on the synergy of the selected targets; (3) structural format selection needs to be extensively tested in vitro as well as in vivo before final format can be determined, especially since the nature and the cellular distribution of the two targets addressed by the developing BsAb are complex.

Additionally, the design of effective bispecific therapeutic molecules should take into full consideration the characteristics of the tumor microenvironment (TME) where a lot of immune suppressive cells reside along with tumor cells that are smart and can always find a way to evade immune cell attack (Fig. 1). For instance, tumor cells can upregulate the ligands for ICPs such as PD-L1 [55, 56] and FGL-1 [57], upregulate epigenetic silencing genes such as enhancer of zeste homolog 2 (EZH2) [58], and/or secrete a large amount of soluble immune suppressive factors such as TGF- $\beta$ and VEGF $[59,60]$. Therefore, rationales of target as well as IgG format selection in BsAb development in general should be built upon the following factors: (1) biological synergy of the targets; (2) cellular distributions; and (3) Fcmediated effector functions (such as ADCC/ADCP). Arbitrary construction of a dual-target molecule without thoroughly understanding the back-end mechanisms will have less likelihood of clinical success.

\section{Selection of IgG subclasses for BsAb against two tumor cell targets}

If both targets are membrane-bound receptors (especially RTK targets) expressed by tumor cells, the IgG1 subclass should be selected. If the corresponding interacting partner of one or both tumor targets is an ICP (such as PD1, SIRPa), IgG1 format will undoubtedly have better efficacy since this format of BsAb could (1) block tumor growth signals; (2) activate innate immune cells via Fc-Fc $\gamma R$ interaction-mediated ADCC/ADCP; (3) activate adaptive immune cells (if one of the interacting partners is ICP such as PD-1).

Taking our CD47xCD20 bispecific molecule (IMM0306) as an example (unpublished data), both CD47 and CD20 are highly expressed in tumor cells (in this case, tumor cell is a B cell), as such, IgG1 format was selected to (1) block the "don't eat me" signal resulting from CD47-SIRP $\alpha$ interaction; and (2) activate innate immune cells via Fc-FcyR interaction (Fig. 2) (unpublished data). In vivo administration of the bispecific molecule at low dose $(1.5 \mathrm{mg} / \mathrm{kg})$ in Daudi xenograft model in SCID mice resulted in complete eradication of the established tumors in 8 of 8 mice, while treatment with rituximab at the dose of $5 \mathrm{mg} / \mathrm{kg}$ led to tumor eradication only in 3 of 8 mice (data not shown). The depletion of macrophages dampened the efficacy of IMM0306, but it was still significantly better than rituximab at the same calculated dose (data not shown), suggesting NK cellmediated ADCC might account for the difference. 


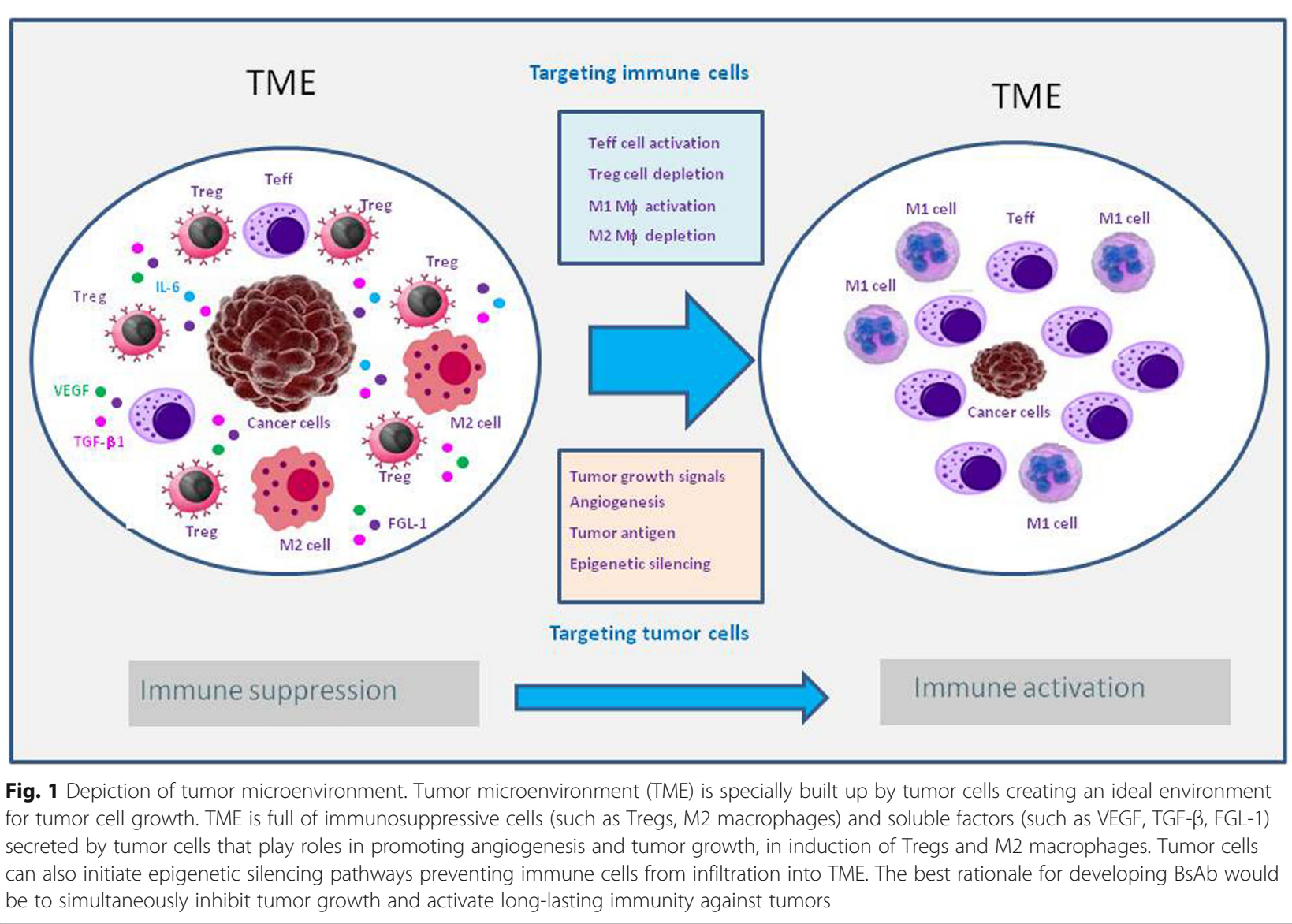

\section{Selection of IgG subclasses for BsAb against two immune cell targets}

If both targets are expressed in immune cells, selecting a subclass becomes much more complicated. To do so, it is necessary to distinguish the biological activity of the targets as well as the types of immune cells.
If both targets are immune checkpoints and are expressed on effector (CD4/CD8) T lymphocytes (e.g., PD-1xTIM-3, PD-1xLAG-3), or on two different immunoactivating cells (such as effector T cells, NK cells (PD$1 \mathrm{xNKG2A}$ ), and M1 macrophages (PD-1xSIRP $\alpha)$ ), the Fc-mediated effector function should be absolutely

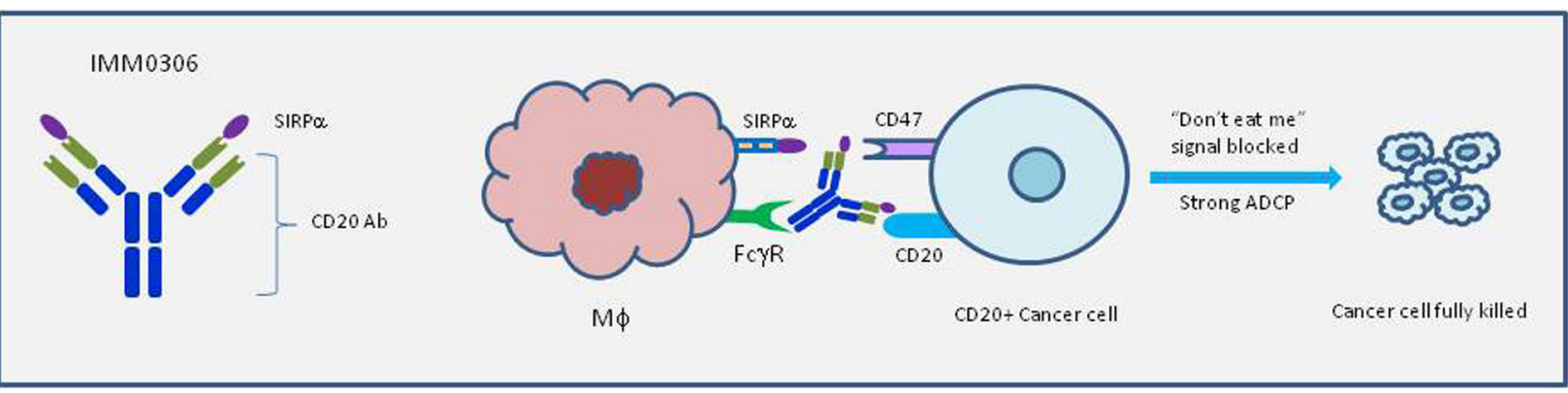

Fig. 2 Working model of CD47xCD20 Bispecific Molecule (IMM0306). IMM0306 targeting CD47xCD20 (Left) is composed of CD20 antibody and the first domain of SIRPa which is connected to the N-terminal of the heavy chain of the antibody. The Fc domain was engineered to have enhanced ADCC/ADCP activity. When administrated, IMM0306 will block the "don't eat me" signal by binding to CD47 and blocking CD47-SIRPa interaction between cancer cells and macrophages, in parallel, it will also strongly activate innate immune cells via Fc-FcyRIIA/FcyRIIIA interaction leading to fully killing of the cancer cells 
avoided, thus IgG2 or IgG4 should be selected. Alternately, the BsAb molecule should exclude the Fc domain so that the activating immune cells would not be eliminated by ADCC/ADCP.

If both targets are expressed on Treg cells (such as CTLA-4xGITR), or one on a Treg cell (CTLA-4) and the other on a MDSC cell (such as CSF1R), or both ICP targets on tumor cells (e.g., PD-L1xCD47), then IgG1 should be selected so that the immunosuppressive cells (Treg, MDSC) or tumor cells over-expressing ICPs (e.g., PD-L1xCD47) can be eliminated via IgG1-mediated ADCC/ADCP.

Pairing of the two targets for BsAb development is also very important and needs to undergo thorough scientific scrutiny before selection. If the two targets were missmatched, then the clinical efficacy would not be reached as originally anticipated, no matter what structural format of the $\mathrm{BsAb}$ is selected. One example of this case is the development of BsAbs targeting PD-1xCTLA-4. Since PD-1 antibody (mostly IgG4) plays its role by blocking the PD-1 signal, and CTLA-4 antibody (IgG1) plays its role mainly by eliminating Treg cells via ADCC/ADCP activity, it is thus unreasonable to develop a BsAb targeting these ICPs, because no matter what IgG subclass (IgG1 or IgG4) is selected, it is impossible to achieve the expected effect. If IgG1 is selected, both Treg cells (highly expressed CTLA4) and PD-1 cells (mainly CD8 T cells) will be eliminated in parallel. If IgG4 is selected, only PD-1 target will be blocked, resulting in $\mathrm{T}$ cell activation because simply blocking CTLA-4 signal has no therapeutic effect $[11,12]$ as exampled by tremelimumab [61, 62]. Proposed IgG subclass for selected target pairs is listed in Table 5.

\section{Selection of IgG subclasses for BsAbs respectively against one tumor cell targets and one immune cell targets}

There is a situation that the two targets are expressed by a tumor cell and an immune cell, respectively. In this

Table 5 Proposed IgG subclass for selected target pairs

\begin{tabular}{|c|c|}
\hline Targets & Proposed lgG \\
\hline PD-1XTIM-3 & $\operatorname{lgG} 4$ \\
\hline PD-1xLAG-3 & $\lg G 4$ \\
\hline PD-1x4-1BB & IgG4, Fc engineering for FcyRIIB engagement \\
\hline PD-1xCD40 & IgG4, Fc engineering for FcyRl|B engagement \\
\hline $\mathrm{PD}-1 \times \mathrm{OX} 40$ & IgG4, Fc engineering for FcyRIIB engagement \\
\hline PD-1xNKG2A & $\lg G 4$ \\
\hline PD-1xSIRPa & $\operatorname{lgG} 4$ \\
\hline PD-L1XCTLA-4 & $\operatorname{|gG} 1$, Fc engineering for $F c \gamma R \| / A / F c \gamma R|| \mid A$ engagement \\
\hline CTLA-4xGITR & IgG1, Fc engineering for $F c \gamma R \||A / F c \gamma R||| A$ engagement \\
\hline CTLA-4xCSF1R & IgG1, Fc engineering for FcyRIIA/FcyRIIIA engagement \\
\hline PD-L1xCD47 & IgG1, Fc engineering for FcyRIIA/FcyRIIIA engagement \\
\hline CD3xTarget2 & IgG4, KIH format \\
\hline
\end{tabular}

case, CD3-based bispecific antibodies are most common, such as CD3xCD19 [63], CD3xCD20 [64], CD3xBCMA [65], CD3-HAC [66]. Because of the expression of CD3 in $\mathrm{T}$ cells, if the structural format is IgG-like, then IgG1 must not be selected. Otherwise, $T$ cells will be eliminated. Instead, IgG2 or IgG4 should be selected and the BsAb was assembled by KIH (knob into hole) platform technology [67].

In recent years, bispecific antibodies have been the popular focus for both preclinical and clinical studies [68-70]. There are many bispecific antibodies in the clinical development stages. As of March 2020, there are a total of 55 registered active clinical trials with different bispecific antibodies from the www.ClinicalTrials.gov website. Although only two BsAb drugs https://www.drugs.com/newdrugs/fda-approves-blincyto-blinatumomab-precursor-b-cell-acute-lymp hoblastic-leukemia-4115.html, https://www.drugs.com/ newdrugs/fda-approves-hemlibra-emicizumab-kxwh-hemo philia-inhibitors-4639.html have been approved by the FDA thus far, it is anticipated that as least five more BsAb drugs could be approved in the coming years.

\section{Selection of IgG subclass format in ADC drug development}

Antibody-drug conjugates (ADCs) are complex molecules composed of antibodies conjugated with cytotoxic payloads via chemical linkers. The well-described mechanism of action for ADC drugs includes [68, 71, 72] (1) binding of the mAb to the target in tumor cells; (2) internalizing the ADC into the cells through receptormediated endocytosis; (3) releasing the cytotoxic payload from the internalized ADC to kill the target cells [73]. The critical requirements for ADC drugs include unique expression of the targets on tumor cells but no or minimal expression in normal tissues, stable linkers that can only be cut inside of the target cells, and targets able to internalize upon antibody binding. While all the relevant information has been well documented, the selection of IgG subclass format for ADC development was less discussed previously.

Although the primary efficacy of ADC drugs is mediated by the toxic payloads delivered by antibodies, the Fc-mediated effector functions may also contribute to the therapy, which is impacted by the expression and cellular distribution of the targets. Among the currently approved five ADC drugs [74] (Table 6), two employed IgG4 antibodies which are lack of effector functions, while all other three employed IgG1, of which brentuximab vedotin has been reported to induce ADCP in vivo and contribute to the potent anti-tumor efficacy for this ADC $[75,76]$. However, other studies have identified Fc receptor engagement by ADC may cause side effects. For example, T-DM1 has been demonstrated to be internalized by megakaryocytes in vivo via FcyRIIA 
Table 6 FDA approved antibody-drug-conjugates (ADCs) [74]

\begin{tabular}{|c|c|c|c|c|}
\hline ADC drugs & Target & Indications & Antibody conjugation & Approval date \\
\hline Adcetris $^{\circledast}$ (brentuximab vedotin) & CD30 & Relapsed $\mathrm{HL}$ and $\mathrm{sALCL}$ & Chimeric IgG1_cysteine & 2011 \\
\hline Kadcyla $^{\oplus}$ (trastuzumab emtansine) & Her2 & Breast cancer & Humanized lgG1_lysine & 2013 \\
\hline Besponsa ${ }^{\oplus}$ (inotuzumab ozogamicin) & CD22 & $r / r$ B-ALL & Humanized lgG4_lysine & 2017 \\
\hline Polivy ${ }^{\circledast}$ (polatuzumab vedotin) & CD79b & $\mathrm{r} / \mathrm{r} \mathrm{DLBCL}$ & Humanized lgG1_cysteine & 2019 \\
\hline Enhertu ${ }^{\circledast}$ (fam-trastuzumab deruxtecan-nxki) & Her2 & Breast cancer & Humanized lgG1_cysteine & 2019 \\
\hline
\end{tabular}

engagement and resulted in the development of thrombocytopenia [77, 78]. Thus, selection of IgG subclass for ADCs should make into consideration of the type of tumors as well as the expression of the targets. For liquid tumors and the targets are restricted only in tumor cells, IgG1 should be selected; otherwise, IgG2 or IgG4 should be primarily considered.

\section{Strategies for manipulating Fc-mediated functions} It has been well confirmed that antibodies with enhanced ADCC activity against some particular targets showed significantly better therapeutic efficacy, while antibodies with increased binding affinity for FcyRIIB showed stronger immune-activating activity if the targets are TNFR superfamily members. Thus, engineering the Fc domain to manipulate the Fc-mediated function has been a hot focus across the pharmaceutical industry.

Several antibodies lacking fucose have been developed either by engineering the Fc domain or by production in cell lines lacking the fucosyltransferase gene. For example, the CD20 antibody obinutuzumab and the CCR4 antibody mogamulizumab were respectively produced in $\mathrm{CHO}$ cells lacking the fucosyltransferase gene $[79,80]$ or $\mathrm{CHO}$ cells lacking both the fucosyltransferase and the fucosyltransporter genes [81]. The removal of the fucose from the Fc portion increased binding affinity with the 158F allele of the FcyRIIIA receptor. Other examples are margetuximab [82] for Her2, and Tafasitamab [83] for CD19, both were developed to enhance ADCC activity by engineering the Fc domain. Clinical trials for the two antibodies all met the primary ends and both were recently submitted to the FDA for marketing approval recently. Margetuximab was reported to have enhanced binding affinity to FcyRIIIA-158F, but a decreased affinity for FcyRIIB, an inhibitory receptor, which allows it to bind more tightly to effector cells and increase ADCC [84]. When compared with Herceptin, the overall survival (OS) for margetuximab-treated breast cancer patients expressing FcyRIIIA-158F was extended by 4.3 months (23.7 months vs 19.4 months) [85].

\section{Conclusions}

In summary, the Fc-Fc $\gamma R$ interaction of a given IgG Fc plays the same important role as the Fab-antigen interaction for anti-tumor antibodies. Thus when designing anti-tumor therapeutic antibodies, extensive consideration should be given to the biological characteristics of the targets, the corresponding cells expressing the targets, and the mechanism of actions proposed for the therapeutic antibodies. If ADCC/ADCP is a must, then IgG1 should be selected, and in most of the cases, the Fc portion should be engineered to increase the binding affinity for the activating Fc $\gamma$ Rs (FcyRIIA, Fc $\gamma$ RIIIA) and/ or remove the binding affinity for the inhibitive $F c \gamma R$ (FcyRIIB). For the immunostimulatory receptors, especially the tumor necrosis factor receptor superfamily receptors (such as CD40, 4-1BB, OX40), improved FcFcyRIIB engagement of the IgG (IgG1 or IgG4) with relatively weak agonistic activity would be the ideal choice for balancing the efficacy and toxicity of the antibodies. In the case of the bispecific antibodies, consideration should be centered on the synergistic effects of the corresponding single-target antibodies and the mechanism of action of the BsAbs, besides the biological characteristics and the cellular distribution of the two targets. Finally, proper pairing of the two targets for BsAb development is of upmost importance. Blindly pairing two targets and arbitrary construction of a dual-target molecule without thoroughly understanding the back-end mechanisms will undoubtedly have less likelihood of clinical success.

\section{Abbreviations}

ADCC: Antibody-dependent cell cytotoxicity; ADCP: Antibody-dependent cell phagocytosis; BsAb: Bispecific antibody; TME: Tumor microenvironment

\section{Acknowledgements}

We are grateful that Dr. Delong Liu from New York Medical College and Westchester Medical Center reviewed the manuscript and gave meaningful suggestions. We specially thank Miss Tina Tian from ModernMD Urgent Care in New York for the grammar editing of the manuscript.

\section{Authors' contributions}

WT designed the study. JY, YS, and WT drafted the manuscript. All authors were involved in manuscript preparation and revisions. All authors read and approved the final manuscript.

\section{Funding}

This study was funded by the Key Scientific Research Project of Henan Provincial Education Department (20A320062) and Special Talents Project Fund of the First Affiliated Hospital of Zhengzhou University, Zhengzhou, China.

Availability of data and materials This is not applicable for this review. 


\section{Ethics approval and consent to participate}

This is not applicable for this review.

\section{Consent for publication}

This is not applicable for this review.

\section{Competing interests}

The authors declare that they have no competing interests.

Received: 27 February 2020 Accepted: 15 April 2020

Published online: 05 May 2020

\section{References}

1. Scott AM, Wolchok JD, Old LJ. Antibody therapy of cancer. Nat Rev Cancer 2012;12(4):278-87.

2. Cooley S, Burns $L J$, Repka T, Miller JS. Natural killer cell cytotoxicity of breast cancer targets is enhanced by two distinct mechanisms of antibodydependent cellular cytotoxicity against LFA-3 and HER2/neu.Exp Hematol. 1999:27(10):1533-1541.

3. Arnould L, Gelly M, Penault-Llorca F, Benoit L, Bonnetain F. MigeonC, et al. Trastuzumab-based treatment of HER2-positive breast cancer: an antibodydependent cellular cytotoxicity mechanism? Br J Cancer. 2006;94(2):259-67.

4. Zhang W, Gordon M, Schultheis AM, Yang DY, Nagashima F, Azuma M, et al. FCGR2A and FCGR3A polymorphisms associated with clinical outcome of epidermal growth factor receptor expressing metastatic colorectal cancer patients treated with single-agent cetuximab. J Clin Oncol. 2007;25(24): 3712-8.

5. Zondor SD, Medina PJ. Bevacizumab: an angiogenesis inhibitor with efficacy in colorectal and other malignancies. Ann Pharmacother. 2004;38(7-8):1258-64.

6. Gemmete JJ, Mukherji SK. Panitumumab (vectibix). AJNR Am J Neuroradiol. 2011;32(6):1002-3.

7. Lin TS. Ofatumumab: a novel monoclonal anti-CD20 antibody. Pharmgenomics Pers Med. 2010;3:51-9.

8. Lin TS, Flinn IW, Modali R, Lehman TA, Webb J, Waymer S, et al. FCGR3A and FCGR2A polymorphisms may not correlate with response to alemtuzumab in chronic lymphocytic leukemia. Blood. 2005;105(1):289-91.

9. Iqbal J, Sun L, Mechanick JI, Zaidi M. Anti-cancer actions of denosumab. Curr Osteoporos Rep. 2011;9(4):173-6.

10. Disis ML. Mechanism of action of immunotherapy. Semin Oncol. 2014 . 41(Suppl 5):S3-13.

11. Du X, Tang F, Liu M, Su J, Zhang Y, Wu W, et al. A reappraisal of CTLA-4 checkpoint blockade in cancer immunotherapy. Cell Res. 2018;28(4):416-32.

12. Du X, Liu M, Su J, Zhang P, Tang F, Ye P, et al. Uncoupling therapeutic from immunotherapy-related adverse effects for safer and effective anti-CTLA-4 antibodies in CTLA4 humanized mice. Cell Res. 2018;28(4):433-47.

13. Yao E, Zhou W, Lee-Hoeflich ST, Truong T, Haverty PM, Eastham-Anderson J, et al. Suppression of HER2/HER3-mediated growth of breast cancer cells with combinations of GDC-0941 PI3K inhibitor, trastuzumab, and pertuzumab. Clin Cancer Res. 2009;15(12):4147-56.

14. Bologna L, Gotti E, Manganini M, Rambaldi A, Intermesoli T, Introna M, et al. Mechanism of action of type II, glycoengineered, anti-CD20 monoclonal antibody GA101 in B-chronic lymphocytic leukemia whole blood assays in comparison with rituximab and alemtuzumab. J Immunol. 2011;186(6): 3762-9.

15. Krupitskaya $Y$, Wakelee HA. Ramucirumab, a fully human mAb to the transmembrane signaling tyrosine kinase VEGFR-2 for the potential treatment of cancer. Curr Opin Investig Drugs. 2009;10(6):597-605.

16. Mamalis A, Garcha M, Jagdeo J. Targeting the PD-1 pathway: a promising future for the treatment of melanoma. Arch Dermatol Res. 2014;306(6):511-9.

17. Gunturi A, McDermott DF. Nivolumab for the treatment of cancer. Expert Opin Investig Drugs. 2015;24(2):253-60.

18. Zeng $Y$, Fest $S$, Kunert $R$, Katinger H, Pistoia $V$, Michon J, et al. Antineuroblastoma effect of ch14.18 antibody produced in $\mathrm{CHO}$ cells is mediated by NK-cells in mice. Mol Immunol. 2005;42(11):1311-9.

19. de Weers M, Tai YT, van der Veer MS, Bakker JM, Vink T, Jacobs DC, et al. Daratumumab, a novel therapeutic human CD38 monoclonal antibody, induces killing of multiple myeloma and other hematological tumors. J Immunol. 2011;186(3):1840-8

20. Campbell KS, Cohen AD, Pazina T. Mechanisms of NK cell activation and clinical activity of the therapeutic SLAMF7 antibody, elotuzumab in multiple myeloma. Front Immunol. 2018;9:2551.
21. Lee HT, Lee JY, Lim H, Lee SH, Moon YJ, Pyo HJ, et al. Molecular mechanism of PD-1/PD-L1 blockade via anti-PD-L1 antibodies atezolizumab and durvalumab. Sci Rep. 2017;7(1):5532.

22. Juliá EP, Amante A, Pampena MB, Mordoh J, Levy EM. Avelumab, an lgG1 anti-PD-L1 immune checkpoint inhibitor, triggers NK cell-mediated cytotoxicity and cytokine production against triple negative breast cancer cells. Front Immunol. 2018;9:2140.

23. Ishii $T$, Ishida $T$, Utsunomiya A, Inagaki A, Yano H, Komatsu $H$, et al. Defucosylated humanized anti-CCR4 monoclonal antibody KW-0761 as a novel immunotherapeutic agent for adult T-cell leukemia/lymphoma. Clin Cancer Res. 2010;16(5):1520-31.

24. Migden MR, Rischin D, Schmults CD, Guminski A, Hauschild A, Lewis KD, et al. PD-1 blockade with cemiplimab in advanced cutaneous squamouscell carcinoma. N Engl J Med. 2018;379(4):341-51.

25. Schur PH. IgG subclasses. A historical perspective. Monogr Allerg. 1988;23:1-11.

26. Vidarsson G, Dekkers G, Rispens T. IgG subclasses and allotypes: from structure to effector functions. Front Immunol. 2014;5:520.

27. Bruhns $P$, lannascoli B, England P, Mancardi DA, Fernandez N, Jorieux S, et al. Specificity and affinity of human Fcgamma receptors and their polymorphic variants for human IgG subclasses. Blood. 2009;113(16):3716-25.

28. Stewart R, Hammond SA, Oberst M, Wilkinson RW. The role of Fc gamma receptors in the activity of immunomodulatory antibodies for cancer. Journal for ImmunoTherapy of Cancer. 2014;2:29.

29. Bruhns $P$. Properties of mouse and human $\lg G$ receptors and their contribution to disease models. Blood. 2012:119(24):5640-9.

30. Graziano RF, Engelhardt JJ. Role of FcyRs in antibody-based cancer therapy. Curr Top Microbiol Immunol. 2019:423:13-34.

31. DiLillo DJ, Ravetch JV. Fc-receptor interactions regulate both cytotoxic and immunomodulatory therapeutic antibody effector functions. Cancer Immunol Res. 2015:3(7):704-13.

32. Sun Z, Fourcade J, Pagliano O, Chauvin JM, Sander C, Kirkwood JM, et al. IL10 and PD-1 cooperate to limit the activity of tumor-specific CD8+ T cells. Cancer Res. 2015;75(8):1635-44.

33. Alsaab HO, Sau S, Alzhrani R, Tatiparti K, Bhise K, Kashaw SK, et al. PD-1 and PDL1 checkpoint signaling inhibition for cancer immunotherapy: mechanism, combinations, and clinical outcome. Front Pharmacol. 2017;8:561.

34. Niwa R, Sakurada M, Kobayashi Y, Uehara A, Matsushima K, Ueda R, et al. Enhanced natural killer cell binding and activation by low-fucose lgG1 antibody results in potent antibody-dependent cellular cytotoxicity induction at lower antigen density. Clin Cancer Res. 2005;11(6):2327-36.

35. Ribas A, Hanson DC, Noe DA, Millham R, Guyot DJ, Bernstein SH, Canniff PC, et al. Tremelimumab (CP-675,206), a cytotoxic T lymphocyte associated antigen 4 blocking monoclonal antibody in clinical development for patients with cancer. Oncologist. 2007;12(7):873-83.

36. Comin-Anduix B, Escuin-Ordinas H, Ibarrondo FJ. Tremelimumab: research and clinical development. Onco Targets Ther. 2016;9:1767-76.

37. Sharma A, Subudhi SK, Blando J, Scutti J, Vence L, Wargo J, et al. Anti-CTLA4 immunotherapy does not deplete FOXP3+ regulatory T cells (Tregs) in human cancers. Clin Cancer Res. 2019;25(4):1233-8.

38. Li F, Ravetch JV. Inhibitory FCy receptor engagement drives adjuvant and anti-tumor activities of agonistic CD40 antibodies. Science. 2011;333(6045): 1030-4.

39. Dahan R, Barnhart BC, Li F, Yamniuk AP, Korman AJ, Ravetch JV. Therapeutic activity of agonistic, human anti-CD40 monoclonal antibodies requires selective FcgammaR engagement. Cancer Cell. 2006;29(6):820-831.

40. White AL, Chan HT, Roghanian A, French RR, Mockridge Cl, Tutt AL, et al Interaction with FcgammaRIIIB is critical for the agonistic activity of antiCD40 monoclonal antibody. J. Immunol. 2011;187(4):1754-63.

41. Xu Y, Szalai AJ, Zhou T, Zinn KR, Chaudhuri TR, Li X, et al. Fc gamma Rs modulate cytotoxicity of anti-Fas antibodies: implications for agonistic antibody-based therapeutics. J Immunol. 2003;171(2):562-8.

42. Zhang M, Yao Z, Zhang Z, Garmestani K, Goldman CK, Ravetch JV, et al. Effective therapy for a murine model of human anaplastic large-cell lymphoma with the anti-CD30monoclonal antibody, HeFi-1, does not require activating Fc receptors. Blood. 2006;108(2):705-10.

43. Chuntharapai A, Dodge K, Grimmer K, Schroeder K, Marsters SA, Koeppen H, et al. Isotype-dependent inhibition of tumor growth in vivo by monoclonal antibodies to death receptor 4. J Immunol. 2001;166(8):4891-8.

44. Wilson NS, Yang B, Yang A, Loeser S, Marsters S, Lawrence D, et al. An FcY receptor-dependent mechanism drives antibody-mediated target-receptor signaling in cancer cells. Cancer Cell. 2011;19(1):101-13. 
45. Liu X, Zhao Y, Shi H, Zhang Y, Yin X, Liu M, et al. Human immunoglobulin G hinge regulates agonistic anti-CD40 immunostimulatory and antitumour activities through biophysical flexibility. Nat Commun. 2019;10(1):4206.

46. Mimoto F, Katada H, Kadono S, Igawa T, Kuramochi T, Muraoka M, et al. Engineered antibody Fc variant with selectively enhanced FcyRllb binding over both FcyRlla(R131) and FcyRlla(H131). Protein Eng Des Sel. 2013;26(10):589-98.

47. Segal NH, Logan TF, Hodi FS, McDermott D, Melero I, Hamid O, et al. Results from an integrated safety analysis of urelumab, an agonist anti-CD137 monoclonal antibody. Clin Cancer Res. 2017;23(8):1929-36.

48. Fisher TS, Kamperschroer C, Oliphant T, Love VA, Lira PD, Doyonnas R, et al. Targeting of 4-1BB by monoclonal antibody PF-05082566 enhances T-cell function and promotes anti-tumor activity. Cancer Immunol Immunother. 2012;61(10):1721-33.

49. Sznol M, Hodi FS, Margolin K, McDermott DF, Ernstoff MS, Kirkwood JM, et al. Phase I/II study of BMS-663513, a fully-human anti-CD137 agonist monoclonal antibody, in patients with advanced cancer. J Clin Oncol 2008; 26:15 s (suppl; abstr 3007).

50. Jure-Kunkel MN, Calarota S, Girit E, Abraham R, Balimane P, Price K, et al. Functional characterization of fully human anti-CD137 antibodies. In: Proceedings of the 97th Annual Meeting of the American Association for Cancer Research; 2006 Apr 1-5; Washington, DC. Philadelphia, PA: AACR. 2006. Abstract nr 4759 .

51. Chin SM, Kimberlin CR, Roe-Zurz Z, Zhang P, Xu A, Liao-Chan S, et al. Structure of the 4-1BB/4-1BBL complex and distinct binding and functional properties of utomilumab and urelumab. Nat Commun. 2018;9(1):4679.

52. Qi X, Li F, Wu Y, Cheng C, Han P, Wang J, et al. Optimization of 4-1BB antibody for cancer immunotherapy by balancing agonistic strength with FcyR affinity. Nat Commun. 2019;10(1):2141.

53. Chester C, Sanmamed MF, Wang J, Melero I. Immunotherapy targeting 41BB: mechanistic rationale, clinical results, and future strategies. Blood. 2018; 131(1):49-57.

54. Ho SK, Xu Z, Thakur A, Fox M, Tan SS, DiGiammarino E, et al. Epitope and Fcmediated crosslinking, but not high affinity, are critical for antitumor activity of CD137 agonist antibody with reduced liver toxicity. Mol Cancer Ther. 2020 Jan 23. pii: molcanther.0608.2019. doi: https://doi.org/10.1158/1535-7163.

55. Darvin P, Toor SM, Nair VS, Elkord E. Immune checkpoint inhibitors: recent progress and potential biomarkers. Exp. Mol. Med. 2018;50(12):165.

56. Pardoll DM. The blockade of immune checkpoints in cancer immunotherapy. Nat. Rev. Cancer. 2012;12(4):252-64.

57. Wang J, Sanmamed MF, Datar I, Su TT, Ji L, Sun J, et al. Fibrinogen-like protein 1 is a major immune inhibitory ligand of LAG-3. Cell. 2019;176(1-2):334-47.

58. Peng D, Kryczek I, Nagarsheth N, Zhao L, Wei S, et al. Epigenetic silencing of TH1-type chemokines shapes tumour immunity and immunotherapy. Nature. 2015;527(7577):249-53.

59. Roma-Rodrigues C, Mendes R, Baptista PV, Fernandes AR. Targeting tumor microenvironment for cancer therapy. Int J Mol Sci. 2019;20(4). pii: E840.

60. Galon J, Bruni D. Approaches to treat immune hot, altered and cold tumours with combination immunotherapies. Nat Rev Drug Discov. 2019; 18(3):197-218

61. Maio M, Scherpereel A, Calabrò L, Aerts J, Cedres Perez S, Bearz A, et al. Tremelimumab as second-line or third-line treatment in relapsed malignant mesothelioma (DETERMINE): a multicentre, international, randomised, double-blind, placebo-controlled phase 2b trial. Lancet Oncol. 2017;18(9): 1261-73.

62. Calabrò L, Morra A, Giannarelli D, Amato G, D'Incecco A, Covre A, et al. Tremelimumab combined with durvalumab in patients with mesothelioma (NIBIT-MESO-1): an open-label, non-randomised, phase 2 study. Lancet Respir Med. 2018;6(6):451-60.

63. Zhao J, Song Y, Liu D. Recent advances on blinatumomab for acute lymphoblastic leukemia. Experimental Hematology \& Oncology. 2019;8(1):28

64. Engelberts PJ, Hiemstra IH, de Jong B, Schuurhuis DH, Meesters J, Beltran Hernandez I, et al. DuoBody-CD3xCD20 induces potent T-cell-mediated killing of malignant B cells in preclinical models and provides opportunities for subcutaneous dosing. EBioMedicine. 2020;52:102625.

65. Hipp S, Tai YT, Blanset D, Deegen P, Wahl J, Thomas O, et al. A novel BCMA/ CD3 bispecific T-cell engager for the treatment of multiple myeloma induces selective lysis in vitro and in vivo. Leukemia. 2017;31(8):1743-51.

66. Yang Y, Zhang X, Lin F, Xiong M, Fan D, Yuan X, et al. Bispecific CD3-HAC carried by E1A-engineered mesenchymal stromal cells against metastatic breast cancer by blocking PD-L1 and activating T cells. Journal of Hematology \& Oncology. 2019;12(1):46.
67. Xu Y, Lee J, Tran C, Heibeck TH, Wang WD, Yang J, et al. Production of bispecific antibodies in "knobs-into-holes" using a cell-free expression system. MAbs. 2015;7(1):231-42.

68. Liu D, Zhao J, Song Y, Luo X, Yang T. Clinical trial update on bispecific antibodies, antibody-drug conjugates, and antibody-containing regimens for acute lymphoblastic leukemia. J Hematol Oncol. 2019;12(1):15.

69. Lind H, Gameiro SR, Jochems C, Donahue RN, Strauss J, Gulley JLMD, et al Dual targeting of TGF- $\beta$ and PD-L1 via a bifunctional anti-PD-L1/TGF- $\beta R I$ agent: status of preclinical and clinical advances. J Immunother Cancer. 2020;8(1):e000433

70. Labrijn AF, Janmaat ML, Reichert JM, Parren PWHI. Bispecific antibodies: a mechanistic review of the pipeline. Nat Rev Drug Discov. 2019;18(8):585-608.

71. Aujla A, Aujla R, Liu D. Inotuzumab ozogamicin in clinical development for acute lymphoblastic leukemia and non-Hodgkin lymphoma. Biomarker Research. 2019;7(1):9.

72. Yu B, Liu D. Gemtuzumab ozogamicin and novel antibody-drug conjugates in clinical trials for acute myeloid leukemia. Biomarker Research. 2019;7(1):24.

73. Peters C, Brown S. Antibody-drug conjugates as novel anti-cancer chemotherapeutics. Biosci Rep. 2015;35:e00225.

74. Leung D, Wurst JM, Liu T, Martinez RM, Datta-Mannan A, Feng Y. Antibody conjugates-recent advances and future innovations. Antibodies (Basel). 2020;9(1). pii: E2. doi: https://doi.org/10.3390/antib9010002.

75. Weiskopf K, Weissman IL. Macrophages are critical effectors of antibody therapies for cancer. MAbs. 2015;7(2):303-10.

76. Gong Q, Ou Q, Ye S, Lee WP, Cornelius J, Diehl L, et al. Importance of cellular microenvironment and circulatory dynamics in B cell immunotherapy. J Immunol. 2005;174(2):817-26.

77. Uppal H, Doudement E, Mahapatra K, Darbonne WC, Bumbaca D, Shen B-Q, et al. Potential mechanisms for thrombocytopenia development with trastuzumab emtansine (T-DM1). Clin Cancer Res. 2015;21(1):123-33.

78. Zhao H, Gulesserian S, Ganesan SK, Ou J, Morrison K, Zeng Z, et al. Inhibition of megakaryocyte differentiation by antibody-drug conjugates (ADCs) is mediated by macropinocytosis: implications for ADC-induced thrombocytopenia. Mol Cancer Ther. 2017;16(9):1877-86.

79. Satoh M, lida S, Shitara K. Non-fucosylated therapeutic antibodies as nextgeneration therapeutic antibodies. Expert Opin Biol Ther. 2006;6(11):1161-73.

80. Kanda Y, Yamane-Ohnuki N, Sakai N, Yamano K, Nakano R, Inoue M, et al. Comparison of cell lines for stable production of fucose-negative antibodies with enhanced ADCC. Biotechnol Bioeng. 2006;94(4):680-8.

81. Niwa R, Natsume A, Uehara A, Wakitani M, lida S, Uchida K, et al. IgG subclass-independent improvement of antibody-dependent cellular cytotoxicity by fucose removal from Asn297-linked oligosaccharides. J Immunol Methods. 2005;306(1-2):151-60.

82. Bang YJ, Giaccone G, Im SA, Oh DY, Bauer TM, Nordstrom JL, et al. First-inhuman phase 1 study of margetuximab (MGAH22), an Fc-modified chimeric monoclonal antibody, in patients with HER2-positive advanced solid tumors. Ann Oncol. 2017;28(4):855-61.

83. Horton HM, Bernett MJ, Pong E, Peipp M, Karki S, Chu SY, et al. Potent in vitro and in vivo activity of an Fc-engineered anti-CD19 monoclonal antibody against lymphoma and leukemia. Cancer Res. 2008;68(19):8049-57.

84. Nordstrom JL, Gorlatov S, Zhang W, Yang Y, Huang L, Burke S, et al. Antitumor activity and toxicokinetics analysis of MGAH22, an anti-HER2 monoclonal antibody with enhanced Fcy receptor binding properties. Breast Cancer Res. 2011;13(6):R123.

85. Rockville, MD, Dec. 11, 2019 (GLOBE NEWSWIRE). MacroGenics presents results from the SOPHIA study of margetuximab in patients with HER2positive metastatic breast cancer at the San Antonio breast cancer symposium http://ir.macrogenics.com/news-releases/news-release-details/ macrogenics-presents-results-sophia-study-margetuximab-patients.

\section{Publisher's Note}

Springer Nature remains neutral with regard to jurisdictional claims in published maps and institutional affiliations. 